\title{
IMPLEMENTASI EXPLICIT SEMANTIC ANALYSIS BERBAHASA INDONESIA MENGGUNAKAN CORPUS WIKIPEDIA INDONESIA
}

\author{
Faisal Rahutomoํㅜ Pramana Yoga Saputra ${ }^{2}$, Carfin Febriawan Pratama Putra ${ }^{3}$
}

Jurusan Teknologi Informasi, Program Studi Teknik Informatika, Politeknik Negeri Malang

faisal@polinema.ac.id ${ }^{1}$, pramanay@gmail.ac.id², cfebriawan@hotmail.com³

\begin{abstract}
Abstrak
Pengembangan terhadap Ujian Online Bahasa Indonesia dalam bentuk esai masih terus dilakukan sampai sekarang guna memperoleh nilai akurasi yang lebih baik dalam memberikan suatu penilaian. Penilaian yang sudah ada saat ini masih menggunakan kemiripan kata pada teks kunci jawaban dan teks jawaban. Cara tersebut memiliki kelemahan mengingat kata dengan tulisan berbeda dapat memiliki makna yang sama. Masalah tersebut dapat diatasi menggunakan skema vektor konsep. Vektor konsep bekerja pada level makna dari sebuah kata. Skema vektor konsep ini dapat diimplementasikan salah satunya menggunakan metode Explicit Semantic Analysis (ESA). Metode ESA memerlukan sebuah korpus yang besar, penelitian ini akan menggunakan korpus dari Artikel Wikipedia Indonesia. Dengan menggunakan metode ESA proses penilaian akan dilakukan dengan membandingkan kemiripan makna dari teks kunci jawaban dengan teks jawaban. Pengujian dilakukan dengan membandingkan 400 teks jawaban soal esai online dengan kunci jawabannya. Dari hasil pengujian tersebut didapatkan kesimpulan bahwa nilai percentage error metode ESA adalah $65 \%$, di mana angka tersebut merupakan probabilitas error yang terlalu tinggi. Pengujian lain yang dilakukan adalah dengan membandingkan nilai percentage error metode ESA dengan metode lain seperti Cosine Similarity, Euclidean Distance, dan Jaccard yang memberikan konklusi bahwa metode ESA tidaklah lebih akurat dari metode-metode lain tersebut.
\end{abstract}

Kata kunci : explicit semantic analysis, pemrosesan teks, soal esay online, wikipedia indonesia

\section{Pendahuluan}

Setiap proses pembelajaran membutuhkan suatu proses evaluasi sebagai sarana untuk menentukan tingkat pemahaman siswa. Evaluasi yang dapat diterapkan cukup beragam seperti menggunakan soal pilihan ganda, isian singkat hingga esai. Beberapa penelitian mengungkapkan bahwa soal pilihan ganda dan isian singkat masih dirasa kurang memadai dalam mengukur tingkat pemahaman siswa. Sebaliknya, evaluasi materi pembelajaran dalam bentuk esai akan lebih akurat dalam menentukan tingkat pemahaman siswa karena siswa diharuskan menuliskan informasiinformasi yang diketahui secara detail dalam menjawab pertanyaan yang diajukan.

Saat ini, perkembangan sistem informasi untuk membantu dalam mengevaluasi pemahaman siswa terhadap proses belajar mengajar sudah cukup banyak. Sistem informasi tersebut telah memiliki fasilitas ujian online baik dalam bentuk pilihan ganda, jawaban singkat, dan esai. Namun, pengembangan terhadap ujian online dalam bentuk esai masih terus dilakukan sampai sekarang. Pengembangan tersebut perlu dilakukan agar didapatkan nilai akurasi yang lebih baik dalam memberikan suatu penilaian.
Telah banyak penelitian yang telah dilakukan untuk menemukan metode yang paling baik dalam menghitung penilaian hasil jawaban soal esai online. Beberapa penelitian mengenai ujian esai berbahasa Indonesia adalah sebagai berikut Penilaian Esai Jawaban Bahasa Indonesia Menggunakan Metode SVM-LSA dengan Fitur Generik yang menghasilkan keakurasian 73\% (Adhitia, 2009), An Attempt to Create an Automatic Scoring Tool for Short Text Answer in Bahasa Indonesia pada aplikasi moodle memiliki standar deviasi sebesar 3-30 dari berbagai macam jenis data yang diujikan (Thamrin, 2004), Perbandingan Algoritma TF/IDF dan BLEU untuk Penilaian Jawaban Esai Otomatis yang menghasilkan nilai korelasi 0.7 (Nugroho, 2014), Analisis AspekAspek Ujian Esai Daring Berbahasa Indonesia yang telah menggunakan perbandingan antara vektorvektor kemiripan antar kedua teks (Trisna, 2016).Dari beberapa hasil penelitian tersebut dapat dilihat bahwa penelitian menggunakan skemavektor konseppada teks masih jarang digunakan. Vektor konsep bekerja pada level makna dari sebuah kata, artinya dua kata yang memiliki tulisan berbeda bisa saja memiliki makna yang sama (misal: kata yang bersinonim). Dalam kasus ini adalah kemiripan antara teks kunci jawaban soal esai dengan teks hasil jawaban siswa. 
Metode yang digunakan untuk menerapkan skema vektor konsep adalah Explicit Semantic Analysis (ESA). Metode ESA memerlukan sebuah matriks yang berisikan vektor kata. Vektor kataini diperoleh melalui text pre-processing dari sebuah corpusteks yang sangat besar yang dalam hal ini penulis menggunakan artikel Wikipedia bahasa Indonesia. Penulis melakukan penelitian tentang "Implementasi Explicit Semantic Analysis (ESA) berbahasa Indonesia menggunakan corpus Wikipedia Bahasa Indonesia" guna meningkatkan tingkat akurasi penilaian jawaban soal esai online.

\section{Tinjauan Pustaka}

\subsection{Text Mining}

Text mining adalah proses menganalisis teks untuk mengekstrak informasi yang berguna untuk tujuan tertentu. Text mining memiliki tugas yang lebih kompleks karena melibatkan data teks yang sifatnya tidak terstruktur dan kabur (fuzzy). Text mining merupakan bidang multi-disiplin yang melibatkan analisis teks, ekstraksi informasi, clustering, kategorisasi, visualisasi, teknologi basis data, machine learning, dan data mining. Perbedaan mendasar antara text mining dan data mining terletak pada sumber data yang digunakan. Pada data mining, pola-pola diekstrak dari basis data yang terstruktur, sedangkan di text mining, polapola diekstrak dari data tekstual (natural language).

1. Case Folding dan Tokenizing. Case folding adalah mengubah semua huruf dalam dokumen menjadi huruf kecil. Hanya huruf a sampai dengan $\mathbf{z}$ yang diterima. Karakter selain huruf dihilangkan dan dianggap delimiter. Tahap tokenizing adalah tahap pemotongan string input berdasarkan tiap kata yang menyusunnya.

2. Filtering. Filtering adalah tahap mengambil kata-kata penting dari hasil proses tokenizing. Terdapat beberapa algoritma dalam filtering yaitu stop-list dan word-list. Algoritma stoplist merupakan algoritma yang digunakan untuk mengeliminasi kata-kata yang tidak deskriptif. Algoritma word-list adalah algoritma yang digunakan untuk menyimpan kata-kata memiliki nilai deskriptif.

3. Stemming. Stemming adalah proses untuk memecahkan setiap varian-varian suatu kata menjadi kata dasar. Proses stemming pada kata Bahasa Indonesia berbeda dengan stemming pada kata Bahasa Inggris. Proses stemming pada kata Bahasa Inggris adalah proses untuk mengeliminasi sufiks pada kata sementara proses stemming pada Bahasa Indonesia adalah proses untuk mengeliminasi sufiks, prefiks dan konfiks. Terdapat beberapa algoritma dalam stemming bahasa Indonesia, antara lain algoritma Porter dan algoritma Nazief \& Adriani.
4. Analyzing. Tahap Analyzing merupakan tahap penentuan seberapa jauh kemiripan antar dokumen teks. Terdapat beberapa metode untuk menentukan kemiripan antar dokumen teks antara lain metode Euclidean Distance, metode Cosine Similarity, metode Jaccard Coefficient, dll. Metode tersebut menggunakan persamaan matematika dalam menentukan nilai kemiripan antar berkas dokumen teks.

\subsection{Explicit Semantic Analysis (ESA)}

Metode ESA merupakan metode yang merepresentasikan sebuah world knowledge yang besar ke dalam sebuah matriks kata (term). Dalam hal ini, world knowledge yang digunakan adalah artikel Wikipedia bahasa Indonesia. Matriks yang digunakan adalah matriks I dengan ukuran $n \times \boldsymbol{m}$, di mana $\boldsymbol{n}$ adalah jumlah kata dan $\boldsymbol{m}$ adalah jumlah artikel atau konsep yang ada pada Wikipedia bahasa Indonesia.

$$
\mathbf{I}=\left(\begin{array}{ccccc}
i_{1,1} & \cdots & i_{1,2} & \cdots & i_{1, m} \\
\vdots & \ddots & \vdots & \ddots & \vdots \\
i_{2,1} & \cdots & i_{2,2} & \cdots & i_{2, m} \\
\vdots & \ddots & \vdots & \ddots & \vdots \\
i_{n, 1} & \cdots & i_{n, 2} & \cdots & i_{n, m}
\end{array}\right)
$$

Kemudian, metode ESA akan men-transpose matriks tersebut menjadi matriks $\mathbf{I}^{\mathrm{T}}$ dengan ukuran $\boldsymbol{m} \times \boldsymbol{n}$.

$$
\mathbf{I}^{\mathrm{T}}=\left(\begin{array}{ccccc}
i_{1,1} & \cdots & i_{1,2} & \cdots & i_{1, n} \\
\vdots & \ddots & \vdots & \ddots & \vdots \\
i_{2,1} & \cdots & i_{2,2} & \cdots & i_{2, n} \\
\vdots & \ddots & \vdots & \ddots & \vdots \\
i_{m, 1} & \cdots & i_{m, 2} & \cdots & i_{m, n}
\end{array}\right)
$$

Setelah matriks $\mathbf{I}^{\mathrm{T}}$ terbentuk, terdapat dua tahap yang harus dilakukan, yang pertama yaitu melakukan konversi dari vektor termx (dengan panjang $\boldsymbol{n}$ ) menjadi vektor konsep $\mathbf{v}$ (dengan panjang $\boldsymbol{m}$ ) dengan cara melakukan proses perkalian antara matriks $\mathbf{I}^{\mathrm{T}}$ dengan vektor $\mathbf{x}$.

$$
\mathbf{v}=\mathbf{I}^{\mathrm{T}} \mathbf{x}
$$

Yang dapat digambarkan secara detail sebagai berikut:

$$
\left(\begin{array}{c}
v_{1} \\
\vdots \\
v_{2} \\
\vdots \\
v_{m}
\end{array}\right)=\left(\begin{array}{ccccc}
i_{1,1} & \cdots & i_{1,2} & \cdots & i_{1, n} \\
\vdots & \ddots & \vdots & \ddots & \vdots \\
i_{2,1} & \cdots & i_{2,2} & \cdots & i_{2, n} \\
\vdots & \ddots & \vdots & \ddots & \vdots \\
i_{m, 1} & \cdots & i_{m, 2} & \cdots & i_{m, n}
\end{array}\right)\left(\begin{array}{c}
x_{1} \\
\vdots \\
x_{2} \\
\vdots \\
x_{n}
\end{array}\right)
$$

Setelah itu dilanjutkan ke tahap kedua yaitu dilakukan tahap pengukuran persamaan antara dua buah vektor konsep $\mathbf{u}$ dan $\mathbf{v}$ yang dilakukan menggunakan rumus cosine similarity. 


\subsection{Cosine Similarity}

Cosine Similarity merupakan metode perhitungan jarak antara vektor A dan B yang menghasilkan sudut cosine $x$ di antara kedua vektor tersebut. Nilai sudut kosinus antara dua vektor menentukan kesamaan dua buah objek yang dibandingkan di mana nilai terkecil adalah 0 dan nilai terbesar adalah 1. Berikut rumus metode perhitungan Cosine Similarity:

$$
\cos (\theta)=\frac{A \cdot B}{\|A\|\|B\|}=\frac{\sum_{i=1}^{n} A_{i} B_{i}}{\sqrt{\sum_{i=1}^{n} A_{i}^{2}} \sqrt{\sum_{i=1}^{n} B_{i}^{2}}}(5)
$$

Dengan $A \cdot B$ merupakan dot product. Dot product merupakan nilai yang mengekspresikan sudut antara dua vektor. Dot product merupakan skalar nilai hasil dari operasi dua vektor yang memiliki jumlah komponen yang sama. Jika vektor A dan B memiliki komponen sebanyak $n$, maka dot product dapat dihitung dengan rumus berikut:

$$
A \cdot B=A_{1} B_{1}+\cdots+A_{n} B_{n}(6)
$$

Dot product dapat dihitung dengan menjumlahkan product dari masing-masing komponen pada kedua vektor. Jika vektor A dan vektor B merupakan vektor 3 dimensi, maka perhitungan dot product adalah sebagai berikut:

$$
A \cdot B=A_{x} * B_{x}+A_{y} * B_{y}+A_{z} * B_{z}
$$

Sedangkan $|A|$ merupakan panjang vektor. Panjang vektor dapat dihitung dengan rumus sebagai berikut :

$$
|A|=\sqrt{X_{1}^{2}+X_{2}{ }^{2}+X_{3}{ }^{2}}
$$

Perhitungan untuk menentukan nilai persentase kemiripan antar dokumen teks, maka persentase kemiripan didapat dengan mengalikan nilai Cosine Similarity terhadap 100. Berikut rumus untuk menentukan nilai persentase kemiripan:

$$
\operatorname{Kemiripan}(\%)=\cos (A, B) \cdot 100
$$

\section{Metodologi}

Metode penelitian yang digunakan dalam merancang Sistem Aplikasi untuk Implementasi Explicit Semantic Analysis (ESA) Berbahasa Indonesia Menggunakan Corpus Wikipedia Indonesia, yang dapat dilihat pada Gambar 1.

\subsection{Studi Literatur}

Pada tahapan ini penelitian dilakukan dengan cara mempelajari berbagai literatur melalui pengumpulan dokumen-dokumen, referensi- referensi, buku-buku, sumber dari internet, maupun sumber lain yang mendukung dan diperlukan dalam perancangan sistem.

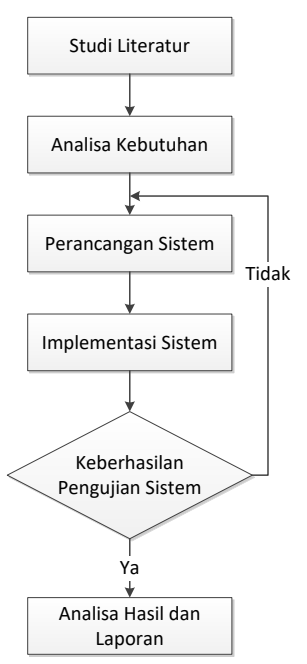

Gambar 1. Metodologi pelaksanaan

\subsection{Analisa Kebutuhan}

Terdapat beberapa analisa kebutuhan antara lain meliputi kebutuhan perangkat lunak (software), perangkat keras (hardware), kebutuhan pengguna sistem (brainware), dan file dump artikel Wikipedia bahasa Indonesia. Spesifikasi minimum perangkat lunak yang digunakan dalam penelitian ini dapat dilihat pada Tabel 1. Sedangkan spesifikasi minimum perangkat keras yang digunakan padapenelitian ini dapat dilihat pada Tabel 2 .

Tabel 1. Spesifikasi minimum perangkat lunak

\begin{tabular}{|l|l|}
\hline $\begin{array}{l}\text { Perangkat } \\
\text { Lunak }\end{array}$ & \multicolumn{1}{c|}{ Keterangan } \\
\hline Windows 7 & $\begin{array}{l}\text { Sistem Operasi yang digunakan } \\
\text { untuk menjalankan sistem. }\end{array}$ \\
\hline $\begin{array}{l}\text { Sublime3 atau } \\
\text { PhpStorm }\end{array}$ & $\begin{array}{l}\text { IDE / Aplikasi teks editor untuk } \\
\text { menulis kode program }\end{array}$ \\
\hline $\begin{array}{l}\text { Apache HTTP } \\
\text { Server }\end{array}$ & $\begin{array}{l}\text { Sebagai Web Server dari } \\
\text { website yang akan dibuat. }\end{array}$ \\
\hline MySQL & $\begin{array}{l}\text { Sebagai DBMS yang akan } \\
\text { digunakan. }\end{array}$ \\
\hline PHP & $\begin{array}{l}\text { Sebagai bahasa pemrograman } \\
\text { utama yang digunakan. }\end{array}$ \\
\hline Python & $\begin{array}{l}\text { Sebagai bahasa pemrograman } \\
\text { untuk proses ekstraksi file dump } \\
\text { Wikipedia. }\end{array}$ \\
\hline
\end{tabular}

Tabel 2. Spesifikasi minimum perangkat keras

\begin{tabular}{|l|l|}
\hline Perangkat Keras & \multicolumn{1}{|c|}{ Keterangan } \\
\hline Processor & Intel Core i3 $2.0 \mathrm{GHz}$ \\
\hline RAM & $4 \mathrm{~GB}$ \\
\hline Hard disk & $10 \mathrm{~GB}$ \\
\hline Monitor & Disesuaikan \\
\hline Perangkat Input & Mouse, Keyboard \\
\hline
\end{tabular}


Kebutuhan Pengguna Sistem (Brainware) adalah, pengguna berinteraksi secara langsung dengan sistem. Berdasarkan tugas dan fungsinya dalam sistem ini dibagi menjadi 2 (dua) pengguna sistem. Daftar pengguna sistem dapat dilihat pada Tabel 3.

Tabel 3. Pengguna sistem

\begin{tabular}{|l|l|l|}
\hline No. & Pengguna & \multicolumn{1}{c|}{ Hak Akses } \\
\hline 1. & Administrator & $\begin{array}{l}\text { Memiliki akses terhadap } \\
\text { semua fasilitas sistem. }\end{array}$ \\
\hline 2. & $\begin{array}{l}\text { Pengguna } \\
\text { Umum }\end{array}$ & $\begin{array}{l}\text { Masuk dan keluar } \\
\text { sistem, melakukan } \\
\text { perbandingan dua teks. }\end{array}$ \\
\hline
\end{tabular}

Dalam penelitian ini dibutuhkan sebuah worldknowledge yang cukup besar yaitu artikelartikel yang ada dalam Wikipedia bahasa Indonesia. Wikipedia sudah menyediakan sebuah fasilitas untuk mengunduh data artikel dalam bentuk XML atau format lainnya. Artikel yang akan digunakan adalah artikel Wikipedia bahasa Indonesia tanggal 20 Desember 2016. File dump tersebut dapat diunduh melalui linkhttps://dumps.wikimedia.org/ idwiki/20161220/.Setelah merujuk link tersebut, maka dapat dipilih file XML yang berisikan seluruh artikel terbaru, yaitu dengan memilih linkhttps://dumps.wikimedia.org/idwiki/20161220/i dwiki-20161220-pages-articlesmultistream.xml.bz2.

\subsection{Perancangan Sistem}

Dalam penelitian ini, penulis membagi menjadi beberapa tahapan proses perencanaan. Berikut adalah tahapan-tahapan yang digunakan.

\subsubsection{Text Pre-Processing}

Pada tahapan ini teks artikel Wikipedia maupun teks data uji perlu dilakukan sebuah ekstraksi teks sehingga berubah menjadi data numerik yang dapat diolah yang dapat dilihat pada Gambar 2.

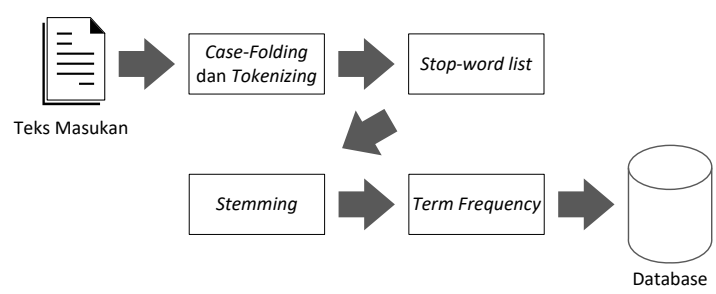

Gambar 2. Proses Text Pre-Processing

Pada Gambar 2, teks masukan yang digunakan adalah artikel Wikipedia bahasa Indonesia dan juga teks data uji (kunci jawaban dan jawaban siswa). Proses Text Pre-Processing pada sistem dibagi menjadi dua kelompok besar berdasarkan alur waktu penerapannya. Dua kelompok proses tersebut dapat dilihat pada Gambar 3.

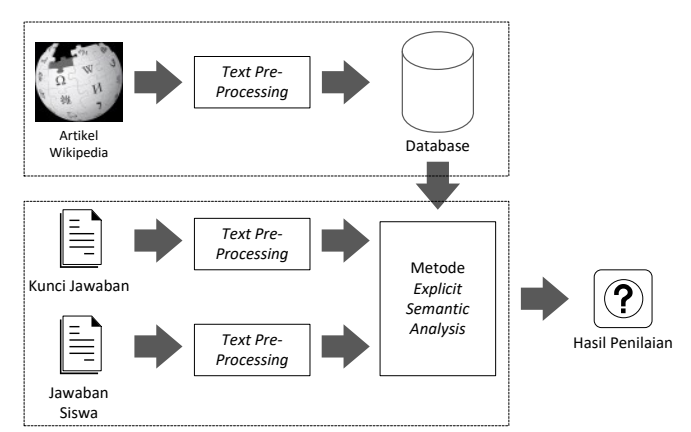

Gambar 3. Pembagian proses Text Pre-processing

Pada Gambar 3 dapat dilihat bahwa ketiga jenis dokumen teks masukan yaitu artikel Wikipedia Indonesia, kunci jawaban, dan jawaban siswa diproses terlebih dahulu melalui tahapan text preprocessing. Namun, tahapan text pre-processing untuk ketiga jenis masukan tersebut dilakukan pada dua kelompok waktu yang berbeda. Untuk kelompok pertama yaitu tahapan text preprocessing pada artikel Wikipedia Indonesia dilakukan hanya satu kali proses saja. Pada kelompok pertama ini tahapan text pre-processing dilakukan untuk membuat indeks matriks yang dibutuhkan pada saat menerapkan metode ESA. Setelah indeks matriks terbentuk, maka proses text pre-processing pada kelompok proses pertama ini tidak akan dilakukan kembali, proses yang dilakukan adalah proses pada kelompok kedua yaitu proses text pre-processing untuk kunci jawaban dan jawaban siswa. Proses pada kelompok kedua ini dilakukan dapat dilakukan berulang kali.

\subsubsection{Implementasi ESA}

Setelah data-data vektor kata sudah disimpan ke dalam database, maka dapat dilakukan pengimplementasian metode ESA terhadap vektorvektor kata tersebut yang dapat dilihat pada Gambar 4.Langkah pertama yaitu mengambil koleksi vektor kata Wikipedia dari database dan membentuknya menjadi indeks matriks di mana nilai TF-IDF vektor katamenjadi nilai kolom dari matriks dan artikel-artikel Wikipedia menjadi nilai baris dari matriks. Indeks matriks yang terbentuk kemudian akan dikalikan dengan vektor kata teks data uji dalam hal ini adalah vektorkatakunci jawaban dan vektor katajawaban siswa. Hasil perkalian kedua vektor tersebut akan menghasilkan dua vektor konsepyaitu vektor konsep kunci jawaban dan vektor konsep jawaban siswa. Kedua vektor konsep inilah yang nantinya digunakan sebagai parameter dalam menghitung kemiripan kedua teks yang dibandingkan. 


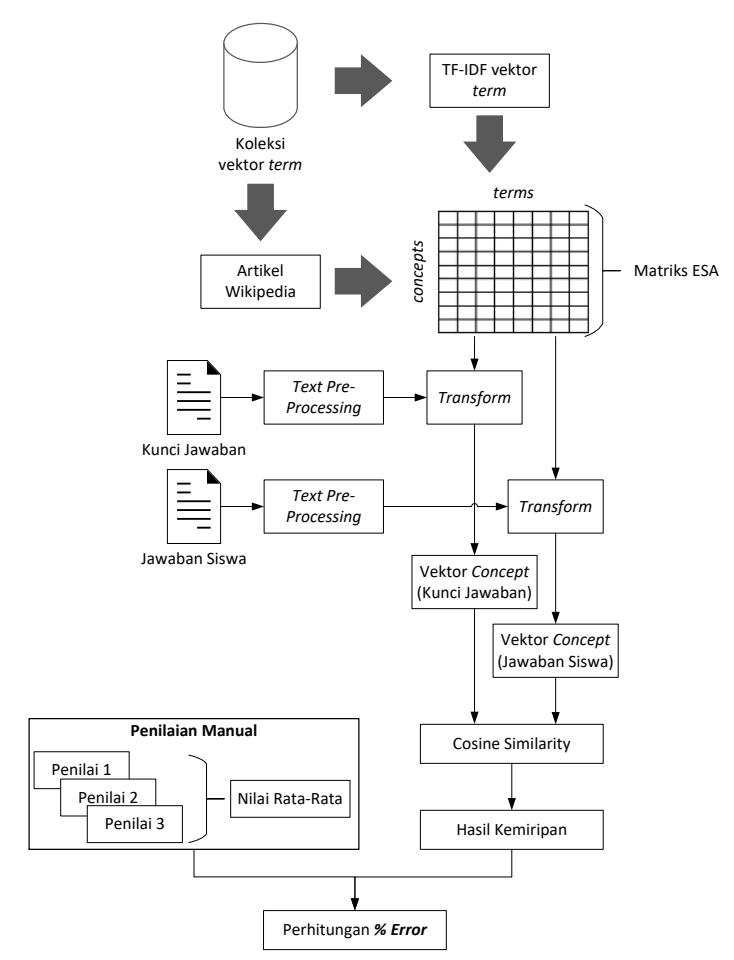

Gambar 4. Rancangan proses ESA

\subsubsection{Pengujian Kemiripan Teks}

Setelah didapatkannya dua buah vektor konsep, maka dilakukan proses perhitungan kemiripan makna antara dua vektor tersebut, yang mana dalam penelitian ini menggunakan rumus cosine simiarity. Hasil nilai kemiripan tersebut kemudian dibandingkan dengan hasil penilaian manual. Perbandingan tersebut akan menghasilkan nilai persentase error terhadap pengujian sistem. Semakin kecil nilai error yang didapatkan artinya penilaian yang dilakukan oleh sistem telah sesuai dengan penilaian yang dilakukan secara manual.

\section{Implementasi}

\subsection{Ekstraksi File Dump Wikipedia}

File dumpWikipedia yang digunakan dalam penelitian ini adalah file dump yang berisikan artikel.Teks artikel tersebut masih belum dalam bentuk plaintext yang sudah siap diproses melainkan dalam bentuk teks yang mengandung kode-kode tertentu yang disebut kode template wikipedia.Untuk menghilangkan kode template tersebut digunakan sebuah ekstraktor. Ekstraktor yang digunakan adalah WikiExtractor versi 2.75 yang merupakan aplikasi third party yang dapat diunduh melalui GitHub.

Hasil ekstraksi WikiExtractor versi 2.75 merupakan sebuah file XML yang berisikan teks artikel yang sudah bersih dari kode template wikipedia dan berukuran jauh lebih kecil dari file dump wikipedia.

\subsection{Memasukkan Hasil Ekstraksi ke Database}

Hasil ekstraksi artikel kemudian dimasukkan ke dalam database melalui sistem yang dibuat.Proses ini membutuhkan waktu sekitar 11 menit dengan total artikel sejumlah 372.829 artikel.

\subsection{Ekstraksi Kata}

Setelah data artikel berhasil dimasukkan, kemudian dilakukan proses ekstraksi kata dari keseluruhan data artikel. Proses ini membutuhkan waktu sekitar 9 jam dengan total kata sejumlah 733.281 kata.

\subsection{Menghitung Nilai TF*IDF}

Setelah data artikel dan kata siap, kemudian dilakukan proses perhitungan nilai TF*IDF. Proses perhitungan nilai TF*IDF dilakukan dalam 3 tahap, yaitu tahap perhitungan nilai $\mathrm{TF}$, perhitungan nilai IDF, dan terakhir perhitungan nilai TF*IDF. Nilai TF*IDF inilah yang menjadi nilai pada indeks matriks ESA.

\subsection{Menghitung Kemiripan Makna}

Setelah indeks matriks berhasil dibuat maka dapat dilakukan perhitungan nilai kemiripan makna dua buah teks. Perhitungan dilakukan dengan cara memasukkan dua buah teks yang ingin dicari kemiripan maknanya. Proses ini membutuhkan waktu sekitar 2-5menit. Proses perhitungan cukup memakan waktu karena dipengaruhi oleh keterkaitan kedua teks yang diuji dengan data pada indeks matriks.

\section{Pengujian}

Pengujian akurasi sistem bertujuan untuk menghitung tingkat keakurasian dari hasil perhitungan oleh sistem. Perhitungan keakurasian sistem dilakukan dengan menggunakan perhitungan percentage error, di mana dilakukan perhitungan perbandingan antara penilaian manual oleh manusia dengan penilaian sistem. Pada penelitian ini untuk menguji tingkat akurasi sistem digunakan data uji penelitian sebelumnya yaitu data uji ujian esai online. Di mana terdapat 400 teks jawaban siswa yang sudah dinilai secara manual oleh seorang guru dan juga sudah dinilai secara sistem menggunakan metode-metode pada penelitian sebelumnya.

Pada penelitian ini pengujian akurasi dilakukan dengan cara menghitung nilai kemiripan teks kunci jawaban dan teks jawaban siswa. Setalah itu dicari nilai percentage error, semakin kecil nilai percentage error yang dihasilkan maka semakin akurat penilaian yang dilakukan oleh sistem. Pengujian lain yang dilakukan adalah membandingkan nilai rata-rata percentage error 
metode ESA dengan metode-metode lain pada penelitian sebelumnya. Tujuan dari pembandingan tersebut adalah untuk mengetahui apakah metode ESA terbukti lebih akurat dari metode-metode sebelumnya. Pada penelitian sebelumnya metode yang digunakan adalah Cosine Similarity, Euclidean Distance, Jaccard, Cosine Similaruty dengan Stemming, Euclidean Distance dengan Stemming, dan Jaccard dengan Stemming.

Tabel 4. Hasil Analisa

\begin{tabular}{|c|c|c|c|c|c|}
\hline$\frac{\stackrel{0}{0}}{\stackrel{0}{0}}$ & 莺 & 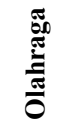 & 苛 & 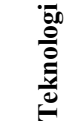 & 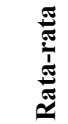 \\
\hline$\%$ Err Cos & 77,4 & 32,8 & 38,1 & 45,5 & 48,4 \\
\hline \% Err Euc & 253,9 & 81,1 & 82,6 & 134,3 & 138,0 \\
\hline \% Err Jac & 66,1 & 51,7 & 48,5 & 53,3 & 54,9 \\
\hline $\begin{array}{l}\text { \% Err Cos } \\
\text { Stemm }\end{array}$ & 75,0 & 32,3 & 40,0 & 42,9 & 47,6 \\
\hline $\begin{array}{l}\text { \% Err Euc } \\
\text { Stemm }\end{array}$ & 252,1 & 80,6 & 81,1 & 131,6 & 136,4 \\
\hline $\begin{array}{l}\text { \% Err Jacc } \\
\text { Stemm }\end{array}$ & 61,8 & 48,6 & 45,8 & 51,0 & 51,8 \\
\hline$\% \operatorname{Err}$ ESA & 96,7 & 50,3 & 58,8 & 56,6 & 65,6 \\
\hline
\end{tabular}

Dari keempat kategori pertanyaan, hasil nilai percentage error rata-rata keseluruhan dapat dilihat pada tabel 4 di atas. Dari tabel 4 tersebut dapat dilihat bahwa nilai percentage error metode ESA adalah $65 \%$ dan menempatkan metode ESA pada peringkat kelima, itu artinya bahwa hipotesis penulis yang beranggapan bahwa dengan memanfaat metode ESA yang mampu bekerja pada level makna kata tidak terbukti dapat meningkatkan nilai akurasi dalam menghitung penilaian soal esai online atau secara umum akurasi perhitungan kemiripan makna.

\section{Kesimpulan dan Saran}

Berdasarkan analisa dan perancangan, implementasi serta pengujian sistem, maka didapatkan kesimpulan sebagai berikut.

Dengan menerapkan text-preprocessing pada teks artikel Wikipedia maka dapat dihasilkan sebuah indeks matriks ESA yang bisa dimanfaat untuk penelitian-penelitian yang berhubungan dengan analisa semantic salah satu contohnya adalah perhitungan kemiripan makna.

Penggunaan metode ESA untuk meningkatkan akurasi penilaian ujian esai online menghasilkan sebuah konklusi yang bertolak belakang dengan hipotesis yang diharapkan penulis, karena setelah dibandingkan dengan hasil perhitungan metodemetode sebelumnya nilai percentage error metode ESA dianggap masih cukup besar yaitu $65 \%$ dan tidak lebih baik atau akurat dengan metode-metode sebelumnya.
Pada penelitian ini ada beberapa saran yang dapat diberikan untuk pengembangan sistem selanjutnya meliputi beberapa hal sebagai berikut.

Penggunaan WikiExtractor untuk membersihkan teks artikel Wikipedia masih dirasa kurang baik karena ada beberapa bagian penting dari teks artikel Wikipedia yang hilang salah satunya adalah teks pada bagian InfoBox.

Hasil ekstraksi kata pada penelitian ini berjumlah lebih dari 700.000 sekian data kata, yang di mana tidak semua kata tersebut merupakan kata yang valid menurut EYD maupun tidak termasuk kata dari suatu istilah. Sehingga bisa dikatakan mayoritas kata yang didapatkan dari hasil ekstraksi merupakan kata yang tidak valid. Diharapkan pada pengembang selanjutnya sistem yang dibuat mampu memberi tagging untuk mengetahui mana kata yang valid dan tidak valid.

\section{Daftar Pustaka:}

Adhitia, R. \& Purwarianti, A. "Penilaian Esai Jawaban Bahasa Indonesia Menggunakan Metode SVM-LSA dengan Fitur Generik". Journal of Information Systems, Volume 5, Issues 1, pp 33. 2009

Azhar Firdaus, Ernawati, dan Arie Vatresia. "Aplikasi Pendeteksi Kemiripan Pada Dokumen Teks Menggunakan Algoritma Nazief \& Adriani Dan Metode Cosine Similarity”. Jurnal Teknologi Informasi, Volume 10 Nomor 1, April 2014

Nugroho, H. W., dkk. "Perbandingan Algoritma TF/IDF dan BLEU untuk Penilaian Jawaban Esai Otomatis”. Edu Komputika Jurnal, pp 43. 2014

Rahutomo, Faisal, et al. "Econo-ESA reduction scheme and the impact of its index matrix density". Procedia Computer Science 35, 2014

Roshinta, Trisna Ari. “Analisa Aspek-Aspek Ujian Esai Daring Berbahasa Indonesia”. Seminar Nasional Terapan Riset Inovatif Semarang, Volume 1. 2016

Thamrin, H., Wantoro, J. "An Attempt to Create an Automatic Scoring Tool of Short Text Answer in Bahasa Indonesia". Proceeding of Internasional Conference on Electrical Engineering, Computer Science and Informatics, pp 96-98. 2014

Witten, Ian H. 2001. "Adaptive Text Mining: Inferring Structure from Sequences" [Online]. Tersedia:

http://www.cs.waikato.ac.nz/ ihw/papers/ 01IHW-Adaptivetextmining.pdf 